\title{
Insights into tectonostratigraphic zone identification in southwestern Newfoundland based on isotopic (Nd, O, Pb) and geochemical data
}

\author{
Joseph B. Whalen ${ }^{1}$, Cees R. van Staal ${ }^{1}$, Frederick J. Longstaffe ${ }^{2}$, \\ Clément Gariépy ${ }^{3}$ and George A. Jenner ${ }^{4}$ \\ ${ }^{1}$ Geological Survey of Canada, 601 Booth Street, Ottawa, Ontario K1A OE8, Canada \\ ${ }^{2}$ Department of Earth Sciences, University of Western Ontario, London, Ontario N6A 5B7, Canada \\ ${ }_{3}^{3}$ Department des Sciences de la Terre and GEOTOP, Université du Québec à Montréal, \\ P.O. Box 8888, Station 'A', Montréal, Québec H3C 3P8, Canada \\ ${ }^{4}$ Department of Earth Sciences, Memorial University of Newfoundland, \\ St. John's, Newfoundland AIB 3X5, Canada
}

Date Received August 3, 1995

Date Accepted November 28, 1997

\begin{abstract}
Plutonic and supracrustal rocks sampled from various tectonostratigraphic divisions in southwestern Newfoundland exhibit a large range in $\mathrm{SiO}_{2}(49$ to $77 \mathrm{wt} . \%), \mathrm{K}_{2} \mathrm{O}(0.9$ to $4.2 \mathrm{wt} . \%), \varepsilon_{\mathrm{Nd}}(\mathrm{T})(-9.2$ to +8.1$), \delta^{18} \mathrm{O}$ (+6.3 to $+12.7 \% 0$ ), and $\mathrm{Pb}$ isotopic ratios. In general, isotopic plus geochemical data are either compatible with, or substantiate, structurally and lithologically based correlations between southwestern Newfoundland and the Central Mobile Belt father north. Such data can thus represent a robust terrane identification tool in highly telescoped or segmented portions of orogenic belts, such as southwestern Newfoundland, and can also provide significant insights into orogen evolution. For example, the Port aux Basques granite (tonalite), which is characterized by MORB-like $\varepsilon_{\mathrm{Nd}}$ $(+8.1)$ and $\delta^{18} \mathrm{O}(+7.5 \%)$ and radiogenic $\mathrm{Pb}\left({ }^{207} \mathrm{~Pb} /{ }^{204} \mathrm{~Pb}=15.818\right)$, is interpreted as a Late Ordovician partialmelt of a juvenile source added to the Gander Zone during Early Ordovician opening of the Exploits back-arc basin. Strongly negative $\varepsilon_{\mathrm{Nd}}(\mathrm{T})$, mantle-like $\delta^{18} \mathrm{O}$, variable $\mathrm{Pb}$ isotopic ratios and metaluminous characteristics of Ordovician plutonism in the Notre Dame arc suggest derivation from Paleoproterozoic or older infracrustal sources. The data indicate formation in an Andean-type continental arc formed on the edge of the Laurentian margin.
\end{abstract}

Les roches plutoniques et supracrustales échantillonnées de divers secteurs tectonostratigraphiques dans le sud-ouest de Terre-Neuve affichent de vastes écarts dans les rapports isotopiques du $\mathrm{SiO}_{2}\left(49\right.$ à $77 \%$ pds), du $\mathrm{K}_{2} \mathrm{O}$ $(0,9$ à $4,2 \% \mathrm{pds})$, du $\varepsilon_{\mathrm{Nd}}(\mathrm{T})(-9,2 \mathrm{a}+8,1)$, du $\delta^{18} \mathrm{O}(+6,3$ à $12,7 \% 0)$ et du $\mathrm{Pb}$. En général, les données isotopiques et géochimiques sont compatibles avec les corrélations structurales et lithologiques entre le sud-ouest de TerreNeuve et la zone orogénique centrale plus au nord, ou elles les corroborent. De telles données peuvent par conséquent représenter un solide outil de caractérisation dans les parties fortement étagées ou segmentées des ceintures orogéniques, comme dans le sud-ouest de Terre-Neuve; elles peuvent en outre fournir des renseignements déterminants sur l'évolution de l'orogène. Par exemple, le granite de Port aux Basques (tonalite), caractérisé par du $\varepsilon_{\mathrm{Nd}}(+8,1)$ de type $M O R B$, du $\delta^{18} \mathrm{O}(+7,5 \%)$ et du $\mathrm{Pb}$ radiogénique $\left({ }^{207} \mathrm{~Pb} / 204 \mathrm{~Pb}=15,818\right)$, est interprété comme du liquide de fusion partiel de l'Ordovicien tardif provenant d'une source juvénile qui s'est ajoutée à la zone de Gander au cours de l'ouverture de l'Ordovicien précoce du bassin arrière-arc d'Exploits. Les rapports isotopiques variables du $\mathrm{Pb}$ de type mantellique $\delta^{18} \mathrm{O}$ de $\varepsilon_{\mathrm{Nd}}(\mathrm{T})$ fortement négatifs et les caractéristiques métalumineuses du plutonisme ordovicien de l'arc de Notre Dame laissent supposer qu'il provient de la période paléo-protérozoïque ou de sources infracrustales plus anciennes. Les données révèlent que la formation présente dans un arc continental de type andin s'est formée sur le bord de la marge laurentienne.

[Traduit par la rédaction]

\section{INTRODUCTION}

Southwestern Newfoundland, an area where the Humber, Dunnage and Gander zones of Williams (1979) converge (Fig. 1), has been interpreted as a product of Silurian collision between promontories on the margins of Laurentia and Gondwana (Lin et al., 1994). High-grade metamorphism, complex deformation, and a series of major faults with extended structural histories render tectonostratigraphic zone identification difficult in this area (van Staal et al., 1991, 1992; Burgess et al., 1992).

Extensive studies of Appalachian granites in New Brunswick (Whalen et al., 1989; Ayuso and Bevier, 1991; Whalen, 1993; Whalen et al., 1994a; Whalen et al., 1996a,b), and other regional investigations in Newfoundland (Fryer et al., 1992; Kerr et al., 1995; Whalen et al., 1997) and Cape Breton Island (Barr and Hegner, 1992), have shown

*Geological Survey of Canada Contribution No. 47994.

Atlantic Geology

33, 231-241 (1997)

$0843-5561 / 97 / 030231-11 \$ 2.65 / 0$ 


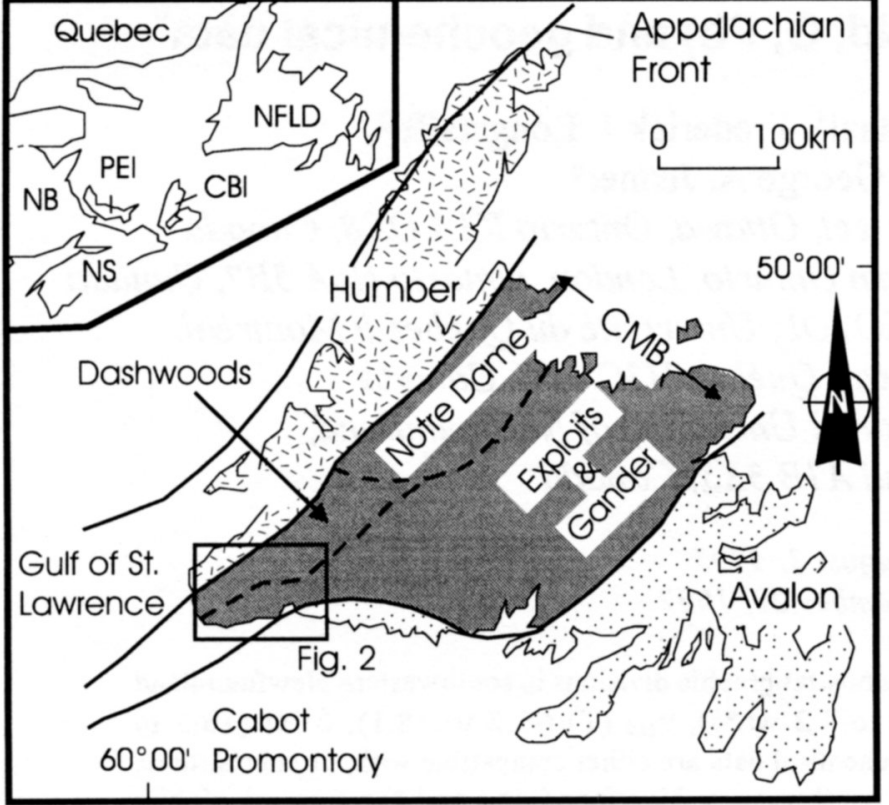

Fig. 1. Tectonostratigraphic zones and subzones of the Newfoundland Appalachians (modified after Williams et al., 1988; Piasecki et al., 1990). CMB is Central mobile belt. In insert, NB is New Brunswick, NS is Nova Scotia, PEI is Prince Edward Island, CBI is Cape Breton Island, and NFLD is Newfoundland.

that significant geochemical and isotopic contrasts exist among plutons emplaced into the different Appalachian tectonostratigraphic zones and that such signatures can be useful for terrane identification. Herein, we present new isotopic $(\mathrm{Nd}, \mathrm{O}, \mathrm{Pb}$ ) and geochemical data from geological units in southwestern Newfoundland and evaluate the usefulness of these data as an aid to, and a check on, structural and tectonic interpretations of this complex continental collisional zone (Figs. 1, 2; Table 1).

\section{Tectonic and geological Context}

The Canadian Appalachian Orogen contains the vestiges of the Early Paleozoic Iapetus Ocean which formerly separated the Laurentian and Gondwanan continents. The western margin (Humber Zone), a Late Neoproterozoic to Early Ordovician passive margin sequence deposited on the edge of Laurentia, was obducted by a Late Cambrian-Early Ordovician suprasubduction-zone oceanic terrane during the Early Ordovician (Cawood and Suhr, 1992). The obduction was followed by formation of a magmatic arc (Notre Dame arc) which contains significant volumes of well preserved, but tectonically disrupted, arc-type plutonic and volcanic rocks in its northern part (Notre Dame subzone) (Fig. 1) (Williams et al., 1988; Whalen et al., 1997). In contrast, the southern part of the Notre Dame arc (Dashwoods subzone) is underlain mainly by high grade supracrustal rocks and penetratively deformed arc-type plutonic rocks, which contain abundant rafts and lenses of dismembered ophiolite and screens of paragneiss (Dunning and Chorlton, 1985; Piasecki et al., 1990; Hall et al., 1994). To the east, the Exploits subzone

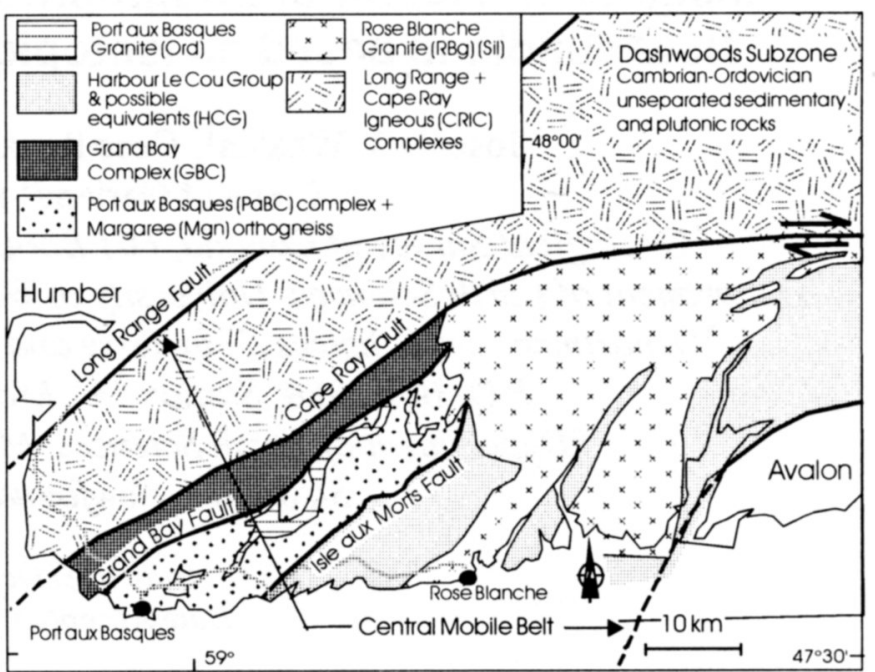

Fig. 2. Map of southwestern Newfoundland with the distribution of tectonic divisions and structures (modified after van Staal et al., 1992; Lin et al., 1994). Division abbreviations as in Tables 1,3 and 4 .

of the Dunnage Zone, dominated by oceanic and arc-type supracrustal rocks, has been interpreted to represent the remnants of Cambrian to Middle Ordovician arc and back-arc basins (Swinden et al., 1990; Jenner and Swinden, 1993; Winchester and van Staal, 1995).

Final closure of oceanic elements in Iapetus is thought to have taken place by westward-directed subduction in Late Ordovician to Early Silurian time (e.g., van Staal, 1994). This closure resulted in collision of the Gander Zone, a continentally derived sedimentary wedge deposited on the edge of Gondwana (van Staal et al., 1996b; Whalen et al., 1996b), plus previously accreted remnants of the Exploits arc plus back arc basin, with the composite Laurentian margin . Collision occurred first in southwestern Newfoundland and Cape Breton Island between promontories on both margins (Lin et al., 1994). The present day crustal structure beneath southwestern Newfoundland is interpreted to comprise a subsurface extension of the Gondwanan continent, which is structurally overlain at higher crustal levels, successively, by attenuated Laurentian crust and a veneer of Dunnage plus Gander zone rocks (Quinlan et al., 1992). These features have been interpreted by Lin et al. (1994) to reflect delamination and tectonic wedging that accompanied the LaurentianGondwanan continental collision during the Silurian.

\section{GeNERAL GEOLOGY OF SOUTHWESTERN NEWFOUNDLAND}

A cross section of the Central Mobile Belt is well exposed in coastal sections east and west of Port aux Basques. These rocks have been subdivided into different lithological and/ or tectonic packages, and tectonostratographic zone correlations have been made (see van Staal et al., 1991, 1992) (Fig. 2). Pertinent features of these subdivisions and some of the justification for the correlations are outlined below, from 
Table 1. Characteristics of sampled units in southwest Newfoundland.

$\begin{array}{llll}\text { Name Sampled Lithology } & \begin{array}{l}\text { Unit } \\ \text { Abbreviation }\end{array} & \begin{array}{l}\text { Division/Zone } \\ \text { or Subzone }\end{array} & \text { Mafics Deformation } \\ \text { Age (Ma)+ References for Ages } \\ \text { Method }\end{array}$

\begin{tabular}{|c|c|c|c|c|c|c|c|}
\hline Cape Ray & granodiorite (tonalite) & CRgd & CRIC/DWsZ & b & $\bmod +a l t$ & $469 \pm 2^{1}$ & Dubé et al. (1996) \\
\hline Cape Ray & porphyritic granodiorite & CRpgd & CRIC/DWsZ & $\mathrm{b}, \mathrm{h}$ & mod+alt & $488 \pm 3^{1}$ & Dubé et al. (1996) \\
\hline Red Rocks & granite & $\mathrm{RRg}$ & CRIC/DWsZ & $b, m$ & sl & $420^{1}$ & Dubé et al. (1996) \\
\hline Grand Bay & granodiorite & GBgd & GBC/EsZ & b & mod to int & $470^{3}$ & van Staal et al. (1994) \\
\hline Port aux Basques & amphibolite dyke & PaBamp & $\mathrm{PaBC} / \mathrm{GZ}$ & $\mathrm{h}$ & sl & $470^{3}$ & van Staal et al. (1994) \\
\hline Port aux Basques & paragneiss & PaBgn & $\mathrm{PaBC} / \mathrm{GZ}$ & $\mathrm{b}$ & $\mathrm{rc}$ & $<500^{3}$ & van Staal et al. (1994) \\
\hline Port aux Basques & granite (tonalite) & $\mathrm{PaBg}$ & $\mathrm{PaBC} / \mathrm{GZ}$ & $\mathrm{b}, \mathrm{h}$ & $\mathrm{rc}$ & $453+ \pm 3^{1}$ & van Staal et al. (1994) \\
\hline $\begin{array}{l}\text { Margaree } \\
\text { Orthogneiss }\end{array}$ & diorite to tonalite & Mgn & $\mathrm{PaBC} / \mathrm{GZ}$ & h,b & $\bmod$ & $470^{1}$ & van Staal et al. (1994) \\
\hline Rose Blanche & granite & $\mathrm{RBg}$ & HCG/EsZ & $b, m$ & sl & $420-414^{2}$ & van Staal et al. (1994) \\
\hline
\end{tabular}

Abbreviations: Mafic minerals: $\mathrm{b}=$ biotite, $\mathrm{h}=$ amphibole, $\mathrm{m}=$ muscovite. Deformation: $\mathrm{sl}=$ slight, $\bmod =$ moderate, int $=$ intense, alt $=$ altered, $\mathrm{rc}=$ recrystallized. Divisions: CRIC = Cape Ray igneous complex, GBC = Grand Bay complex, PaBC = Port aux Basques complex, HCG = Harbour le Cou Group. Zones: $\mathrm{DWs} Z=$ Dashwoods subzone, $\mathrm{EsZ}=$ Exploits subzone, $\mathrm{GZ}=$ Gander Zone. Age methods: 1 . U-Pb zircon; 2 . Pb-Pb monazite; 3 . estimated based on structural relationships; U-Pb ages without errors are preliminary.

west to east. The reader is referred to the above cited sources for a comprehensive treatment. Major characteristics of plutons or units sampled for this study, including rock type, mafic mineral content, deformation state, and age are summarized in Table 1.

Cambrian to Middle Ordovician ophiolitic rocks (Long Range Complex), variably deformed intermediate to felsic plutonic rocks (Cape Ray Igneous Complex; e.g., Cape Ray granodiorite in Table 1), and local paragneisses occur between the Long Range and Cape Ray faults. The Cape Ray Igneous Complex also includes Silurian to Lower Devonian plutons (e.g., Red Rocks granite in Table 1; Dubé et al., 1996). These rocks form the southern part of the Dashwoods subzone, with the Cambro-Ordovician rocks representing remnants of the Notre Dame arc.

The Grand Bay complex, located between the Cape Ray and Grand Bay faults zones, consists of amphibolite-facies paragneiss and mafic and felsic orthogneiss, which includes the Grand Bay granodiorite. On the basis of the lithological correspondence along strike of sedimentary rocks, the Grand Bay complex is correlated with rocks of the Exploits subzone (Chorlton and Knight, 1983; van Staal et al., 1996a).

The Port aux Basques Complex, located between the Grand Bay and Isle aux Morts faults (Fig. 2), consists mainly of paragneiss, intruded by Upper Ordovician (U-Pb zircon of $453 \pm 3 \mathrm{Ma}$; van Staal et al., 1994 and unpublished data) gneissic granitoid sheets (Port aux Basques granite), and abundant amphibolite dikes and sills. The Ordovician (U$\mathrm{Pb}$ zircon of c. $470 \mathrm{Ma}$; van Staal et al., 1994 and unpublished data) Margaree orthogneiss, a mixed mafic and felsic unit, is exposed on the coast east of Channel Port aux Basques
(Fig. 2). Field relationships suggest an originally intrusive relationship between Margaree orthogneiss and the Port aux Basques paragneiss. Deformed amphibolite dykes and sheets, which cut the Margaree orthogneiss, have been interpreted as consanguinous with similar dikes and sills cutting the Port aux Basques paragneiss (Schofield et al., 1993, in press; van Staal et al., 1994). The Port aux Basques Complex is interpreted to represent a structural inlier of Gander Zone rocks that occurs between two segments of Exploits subzone rocks, represented by the Grand Bay complex and the Harbour Le Cou Group. Similar inliers of Gander Zone rocks within Exploits subzone rocks have been mapped and described farther north (e.g., Williams et al., 1988).

The Harbour Le Cou Group, located east of the Isle aux Morts fault, consists of monotonous paragneiss with minor amphibolite. These rocks are interpreted as correlative with the Early to Middle Ordovician Bay du Nord Group of the Exploits subzone. They are intruded by the Late Silurian ( $\mathrm{Pb}-\mathrm{Pb}$ monazite age of ca. 420 to 414; van Staal et al., 1994 and unpublished data) muscovite-garnet-bearing Rose Blanche granite.

\section{Regional Nd, 0 and Pb isotopic context}

The range in $\mathrm{Nd}$ isotopic compositions, expressed as $\varepsilon_{\mathrm{Nd}}$ at $430 \mathrm{Ma}$, and $\delta^{18} \mathrm{O} \%$ (SMOW) obtained from basement, sedimentary and granitoid rocks from interior parts of various Canadian Appalachian tectonostratigraphic zones (Fig. 1) are summarized in Table 2, together with the data sources. Because they may provide 'mixed' signatures (cf. Whalen et al., 1996a), isotopic data from plutons immediately adjacent 
Table 2. Ranges in $\varepsilon_{\mathrm{Nd}}$ at $430 \mathrm{Ma}$ and $\delta^{18} \mathrm{O} \%$ (SMOW) of various units within Canadian Appalachian tectonostratigraphic zones and subzones.

\begin{tabular}{|c|c|c|c|c|c|c|}
\hline \multirow[t]{2}{*}{ Group } & \multirow{2}{*}{$\begin{array}{l}\text { Humber } \\
\text { Zone }\end{array}$} & \multicolumn{3}{|c|}{ Dunnage Zone } & \multirow{2}{*}{$\begin{array}{l}\text { Gander } \\
\text { Zone }\end{array}$} & \multirow{2}{*}{$\begin{array}{l}\text { Avalon } \\
\text { Zone }\end{array}$} \\
\hline & & $\begin{array}{l}\text { Notre Dame } \\
\text { Subzone }\end{array}$ & $\begin{array}{l}\text { Dashwoods } \\
\text { Subzone }\end{array}$ & $\begin{array}{l}\text { Exploits } \\
\text { Subzone }\end{array}$ & & \\
\hline Precambrian & $(-12 /-1)^{1,8}$ & & & & $(-8)^{5}$ & $(-2 /+6)^{2,4}$ \\
\hline Granitoids & $(+7 /+12 \% 0)^{1,8}$ & & & & & $(+2 /+8 \% o)^{1,4}$ \\
\hline$>470 \mathrm{Ma}$ & $(-11)^{1}$ & $(-16 /-11)^{1,8}$ & & & $(-8 /-7)^{4}$ & \\
\hline $\begin{array}{l}\text { Sedimentary } \\
\text { rocks }\end{array}$ & & $(+6 \% 0)^{8}$ & & & $(+10 /+14 \% 0)^{1}$ & \\
\hline $510-440 \mathrm{Ma}$ & & $(-14 /+2)^{8}$ & $(-10 /-6)^{8}$ & $(-2 /+6)^{1,4}$ & $(-7 / 0)^{4,6}$ & \\
\hline Granitoids & & $(+5 /+9 \% 0)^{8}$ & $(+8 /+9 \%)^{8}$ & $(+8 /+9 \% 0)^{1}$ & $(+8 /+10 \% 0)^{1,6}$ & \\
\hline$<440 \mathrm{Ma}$ & $(-8 /+5)^{1,3}$ & $(-2 /+4)^{9,10}$ & $(-10 /+3)^{10}$ & $(-2 /+5)^{1,4}$ & $(-8 /+1)^{4,7}$ & $(+1 /+5)^{2,4}$ \\
\hline Granitoids & $(+6 /+10 \% 0)^{1,3}$ & $(+4 /+8 \% 0)^{9,10}$ & $(+7 /+10 \% \text { o })^{10}$ & $(+7 /+10 \% 0)^{1,3}$ & $(+6 /+10 \% 0)^{1,7}$ & $(+5 /+10 \% 0)^{1,4}$ \\
\hline
\end{tabular}

Sources: ${ }^{1}$ Fryer et al. (1992); Whalen et al. ${ }^{2}$ (1994a), ${ }^{3}$ (1994b); ${ }^{4}$ Kerr et al. (1995); ${ }^{5}$ van Staal et al. (1996); Whalen et al. ${ }^{6}(1996 \mathrm{a}),{ }^{7}(1996 \mathrm{~b}),{ }^{8}(1997),{ }^{9}(1996 \mathrm{c}),{ }^{10}$ (unpublished data). Data from the Brookville terrane in New Brunswick and from adjacent to zone boundaries excluded.

to zone boundaries are not included. Data summarized in Table 2 are sparse for units such as Early Paleozoic metasedimentary rocks but extensive for Paleozoic granites.

Ayuso and Bevier (1991) showed that Paleozoic plutons emplaced into the Laurentian and Gondwanan sides of the northern Appalachian orogen in the U.S.A. and New Brunswick are characterized by contrasting non-radiogenic (Laurentia) versus radiogenic (Gondwana) $\mathrm{Pb}$ isotopic signatures. The authors interpreted these signatures to reflect their presumed Precambrian Grenvillian and Avalonian basement rocks, respectively. Although Ordovician Notre Dame arc plutons mainly display 'Grenville-like' $\mathrm{Pb}$ isotopic compositions, their large range in ${ }^{207} \mathrm{~Pb} / 204 \mathrm{~Pb}$ and ${ }^{206} \mathrm{~Pb} / 204 \mathrm{~Pb}$ ratios overlaps that of Avalonian basement rocks (Whalen et al., 1997); i.e., the mainland Appalachian-based $\mathrm{Pb}$-isotopic terrane signatures of Ayuso and Bevier (1991) may not be directly applicable to Newfoundland.

As interpretations of the reasons for, and significance of, these isotopic variations are complex and not unequivocal, the reader is referred to detailed discussions within sources listed below Table 2 and also to Ayuso and Bevier (1991). Herein, we attempt to employ these isotopic ranges as 'fingerprints' of different tectonostratigraphic zones for the purpose of terrane identification. Their petrogenetic or tectonic implications will be discussed only as regard to our data set from southwestern Newfoundland.

\section{Geochemistry}

Major and trace element compositional data are presented in Table 3 and summarized in Figures 3 and 4; only geochemical features relevent to terrane correlation are discussed in the next section. Isotopic data and UTM co-ordinates for the samples are given in Table 4. Analytical techniques, precision and errors are the same as presented in Whalen et al. (1996b; 1997). Initial ${ }^{143} \mathrm{Nd} /{ }^{144} \mathrm{Nd}$ isotopic ratios are reported as $\varepsilon_{\mathrm{Nd}}$ values (DePaolo, 1988) and O isotopic analyses are reported in parts per thousand (\%) using the normal $\delta$-notation relative to V-SMOW (Vienna Standard Mean Ocean Water) (Baertschi, 1976).

Based on $\mathrm{Sm} / \mathrm{Nd}$ isotopic data, expressed as $\varepsilon_{\mathrm{Nd}}$, the samples can be grouped into those with values $<-5$ and $>0$ (Table 3, Fig. 5). Those with $\varepsilon_{\mathrm{Nd}}<-5$ (Cape Ray Igneous Complex and Port aux Basques paragneiss) were derived from a reservoir(s) or source(s) with a history of long-term LREE enrichment, such as old continental crust. Those with $\varepsilon_{\mathrm{Nd}}>0$ (Grand Bay granodiorite, Margaree orthogneiss, Port aux Basques granite and amphibolite) were derived from a reservoir(s) with a history of slight to strong LREE depletion. The Port aux Basques granite, whose value lies in the range of depleted mantle (DM), was analyzed in duplicate to confirm its strongly positive character.

The $\delta^{18} \mathrm{O}$ values of the samples range from +6.3 to $+12.7 \%$. 
Table 3. Geochemical analyses from units in southwest Newfoundland.

\begin{tabular}{|c|c|c|c|c|c|c|c|c|c|c|c|c|c|}
\hline Division & CRIC & CRIC & CRIC & GBC & GBC & GBC & $\mathrm{PaBC}$ & $\mathrm{PaBC}$ & $\mathrm{PaBC}$ & $\mathrm{PaBC}$ & $\mathrm{PaBC}$ & $\mathrm{PaBC}$ & HCG \\
\hline Unit & CRgd & CRpgd & $R R g$ & GBgd & GBgd & GBgd & PaBamp & PaBgn & PaBgn & $\mathrm{PaBg}$ & $\mathrm{Mgn}$ & $\mathrm{Mgn}$ & $\mathrm{RBg}$ \\
\hline WXNF\# & 31 & 32 & 28 & 166 & 167 & 168 & $30 a$ & $30 c$ & $30 \mathrm{~b}$ & 29 & 170 . & 169 & 171 \\
\hline $\mathrm{SiO}_{2}(\mathrm{wt} . \%)$ & 70.02 & 57.43 & 71.92 & 70.01 & 73.72 & 60.59 & 51.80 & 76.32 & 76.84 & 75.38 & 49.03 & 65.79 & 71.19 \\
\hline $\mathrm{TiO}_{2}$ & 0.36 & 0.67 & 0.20 & 0.57 & 0.30 & 0.80 & 1.97 & 0.73 & 0.97 & 0.26 & 0.89 & 0.83 & 0.30 \\
\hline $\mathrm{Al}_{2} \overline{\mathrm{O}}_{3}$ & 13.51 & 16.29 & 14.81 & 15.10 & $\cdot 13.30$ & 16.20 & 14.51 & 10.85 & 9.89 & 13.31 & 17.76 & 16.20 & 15.30 \\
\hline $\mathrm{Fe}_{2} \mathrm{O}_{3}$ & 1.83 & 3.10 & 0.71 & 0.97 & 0.71 & 2.25 & 5.55 & 1.36 & 1.16 & 1.00 & 2.91 & 1.51 & 0.76 \\
\hline $\mathrm{FeO}$ & 1.43 & 2.43 & 0.53 & 1.90 & 0.80 & 2.50 & 7.67 & 2.07 & 1.93 & 0.60 & 5.30 & 2.30 & 1.15 \\
\hline $\mathrm{MnO}$ & 0.07 & 0.13 & 0.04 & 0.07 & 0.08 & 0.17 & 0.25 & 0.09 & 0.09 & 0.04 & 0.15 & 0.05 & 0.09 \\
\hline $\mathrm{MgO}$ & 1.08 & 2.87 & 0.52 & 1.06 & 0.97 & 2.68 & 4.41 & 1.30 & 1.05 & 0.31 & 7.89 & 1.41 & 0.64 \\
\hline $\mathrm{CaO}$ & 3.39 & 4.87 & 1.90 & 2.36 & 1.63 & 2.85 & 8.21 & 0.93 & 2.35 & 1.43 & 10.96 & 3.09 & 1.59 \\
\hline $\mathrm{Na}_{2} \mathrm{O}$ & 3.19 & 3.25 & 3.86 & 5.54 & 4.32 & 4.07 & 2.28 & 2.07 & 2.83 & 6.43 & 2.94 & 4.27 & 4.75 \\
\hline $\mathrm{K}_{2} \mathrm{O}$ & 1.65 & 3.91 & 4.24 & 1.64 & 3.48 & 3.90 & 0.59 & 2.32 & 0.88 & 0.55 & 0.76 & 3.32 & 3.17 \\
\hline $\mathrm{P}_{2} \mathrm{O}_{5}$ & 0.06 & 0.43 & 0.06 & 0.14 & 0.06 & 0.22 & 0.35 & 0.11 & 0.18 & 0.05 & 0.08 & 0.25 & 0.11 \\
\hline LOI & 3.47 & 3.63 & 0.62 & 0.33 & 0.30 & 3.90 & 0.85 & 1.06 & 0.54 & 0.17 & 0.70 & 0.57 & 0.68 \\
\hline Total & 100.05 & 99.00 & 99.42 & 99.69 & 99.66 & 100.12 & 98.44 & 99.19 & 98.71 & 99.53 & 99.36 & 99.59 & 99.72 \\
\hline $\mathrm{Rb}(\mathrm{ppm})$ & 50 & 118 & 128 & 39 & 80 & 101 & 11 & 87 & 43 & 8 & 9 & 93 & 94 \\
\hline $\mathrm{Ba}$ & 475 & 10 & 1732 & 5 & 1586 & 1684 & 111 & 397 & 169 & 36 & 77 & 1537 & 3 \\
\hline $\mathrm{Sr}$ & 155 & 1168 & 724 & 263 & 148 & 220 & 343 & 111 & 267 & 215 & 185 & 398 & 312 \\
\hline $\mathrm{Ga}$ & $<3$ & 10 & 4 & 16 & 15 & 16 & 12 & $<3$ & $<3$ & 15 & 16 & 19 & 18 \\
\hline $\mathrm{Ta}$ & 1.3 & 1.3 & 2.2 & 3.0 & 2.7 & 1.4 & 1.0 & 1.5 & 2.7 & 4.8 & 1.0 & 2.9 & 3.1 \\
\hline $\mathrm{Nb}$ & 5.4 & 14.2 & 6.9 & 9.4 & 11.4 & 9.1 & 6.4 & 11.8 & 16.0 & 52.1 & 1.7 & 16.5 & 15.2 \\
\hline $\mathrm{Hf}$ & 1.7 & 7.3 & 3.4 & 8.0 & 5.7 & 7.8 & 4.6 & 5.9 & 17.6 & 5.4 & 1.7 & 10.8 & 5.9 \\
\hline $\mathrm{Zr}$ & 63 & 278 & 114 & 300 & 162 & 275 & 162 & 246 & 654 & 213 & 54 & 445 & 203 \\
\hline $\mathrm{Y}$ & 5 & 16 & 5 & 18 & 19 & 24 & 37 & 23 & 37 & 37 & 20 & 17 & 9 \\
\hline Th & 1.4 & 21.2 & 13.8 & 16.5 & 16.9 & 10.2 & 3.8 & 8.8 & 14.5 & 15.6 & 0.8 & 30.2 & 14.8 \\
\hline $\mathrm{U}$ & $<4$ & 8 & 5 & $<4$ & $<4$ & $<4$ & $<4$ & $<4$ & 4 & 5 & $<4$ & $<4$ & $<3$ \\
\hline $\mathrm{La}$ & 9.1 & 92.9 & 33.0 & 23.3 & 35.9 & 22.4 & 15.1 & 29.9 & 38.9 & 42.2 & 3.2 & 84.6 & 61.9 \\
\hline $\mathrm{Ce}$ & 16.2 & 184.4 & 60.5 & 54.1 & 67.4 & 48.1 & 34.6 & 63.8 & 83.3 & 82.5 & 8.0 & 159.5 & 117.1 \\
\hline $\mathrm{Pr}$ & 1.6 & 20.2 & 6.3 & 5.3 & 7.4 & 5.7 & 4.4 & 7.3 & 9.9 & 9.0 & 1.2 & 16.6 & 12.0 \\
\hline Nd & 5.6 & 68.5 & 20.0 & 19.0 & 26.7 & 22.4 & 18.9 & 27.7 & 36.9 & 30.6 & 6.2 & 56.6 & 38.8 \\
\hline $\mathrm{Sm}$ & 0.99 & 9.74 & 2.64 & 3.81 & 4.57 & 4.69 & 4.82 & 5.33 & 7.41 & 5.90 & 2.08 & 9.33 & 5.61 \\
\hline $\mathrm{Eu}$ & 0.63 & 2.02 & 0.54 & 0.96 & 0.91 & 1.52 & 1.63 & 1.10 & 1.37 & 0.74 & 0.85 & 1.80 & 1.22 \\
\hline $\mathrm{Gd}$ & 0.81 & 5.50 & 1.20 & 3.00 & 3.80 & 4.61 & 5.45 & 4.66 & 6.06 & 4.77 & 3.05 & 6.21 & 3.50 \\
\hline Tb & 0.10 & 0.63 & 0.12 & 0.49 & 0.59 & 0.70 & 0.89 & 0.71 & 0.95 & 0.79 & 0.48 & 0.79 & 0.41 \\
\hline Dy & 0.68 & 3.26 & 0.73 & 3.42 & 3.67 & 4.70 & 5.68 & 4.31 & 5.85 & 5.07 & 3.67 & 4.36 & 2.33 \\
\hline Ho & 0.14 & 0.56 & 0.13 & 0.71 & 0.70 & 0.91 & 1.22 & 0.86 & 1.20 & 1.02 & 0.75 & 0.72 & 0.39 \\
\hline Er & 0.39 & 1.45 & 0.37 & 2.00 & 2.06 & 2.69 & 3.46 & 2.42 & 3.56 & 3.07 & 2.06 & 1.81 & 1.05 \\
\hline $\mathrm{Tm}$ & 0.06 & 0.19 & 0.05 & 0.30 & 0.28 & 0.00 & 0.50 & 0.33 & 0.52 & 0.47 & 0.31 & 0.23 & 0.15 \\
\hline $\mathrm{Yb}$ & 0.33 & 1.19 & 0.35 & 2.15 & 1.85 & 2.65 & 3.22 & 2.22 & 3.60 & 3.20 & 1.96 & 1.41 & 0.91 \\
\hline $\mathrm{Lu}$ & 0.06 & 0.18 & 0.06 & 0.35 & 0.29 & 0.42 & 0.51 & 0.33 & 0.58 & 0.47 & 0.31 & 0.19 & 0.15 \\
\hline $\mathrm{Cr}$ & 20 & 43 & 11 & 16 & 20 & 18 & 33 & 56 & 70 & 11 & 290 & 32 & 16 \\
\hline $\mathrm{Ni}$ & $<4$ & 12 & $<4$ & 27 & 31 & 30 & 10 & 16 & 10 & $<4$ & 130 & 35 & 32 \\
\hline Sc & 14 & 14 & $<7$ & 10 & $<7$ & 15 & 38 & $<7$ & 11 & 9 & 38 & $<7$ & $<7$ \\
\hline V & 61 & 135 & 15 & 50 & $<6$ & 92 & 439 & 55 & 42 & $<6$ & 212 & 72 & 9 \\
\hline $\mathrm{Cu}$ & 9 & $<3$ & $<3$ & 35 & 22 & $<3$ & 47 & 8 & 31 & $<3$ & 65 & 43 & 4 \\
\hline $\mathrm{Pb}$ & 10 & 24 & 29 & 19 & 11 & 9 & 15 & 12 & 15 & $<4$ & $<4$ & 11 & 23 \\
\hline$Z n$ & 21 & 63 & $<10$ & 20 & $<10$ & 51 & 123 & 20 & $<10$ & $<10$ & 59 & 62 & 40 \\
\hline$S$ & 124 & 34 & 14 & 118 & 127 & 89 & 506 & 175 & 534 & 21 & 549 & 267 & 98 \\
\hline $\mathrm{F}$ & 82 & 995 & 390 & 825 & 298 & 233 & 625 & 320 & 155 & 215 & 623 & 1080 & 278 \\
\hline $\mathrm{Cl}$ & 35 & 63 & 44 & $<20$ & 23 & 70 & $<20$ & $<20$ & 28 & 23 & 102 & 100 & 219 \\
\hline ASI & 1.02 & 0.88 & 1.03 & 1.00 & 0.96 & 1.01 & 0.75 & 1.43 & 1.00 & 0.97 & 0.69 & 1.00 & 1.08 \\
\hline
\end{tabular}

Notes: Pluton names corresponding to pluton\# codes in Table 1; locations of divisions given in Figure 2. LOI = loss on ignition: ASI = aluminium staturation index (mol. proportion $\mathrm{Al} /(\mathrm{Ca}+\mathrm{Na}+\mathrm{K})$.

Samples between +6 and $+8 \%$ (Cape Ray Igneous Complex, Grand Bay granodiorite and Port aux Basques granite) overlap the range of juvenile or mantle-derived magmas (Fig. 5).
Almost all other samples, including one Port aux Basques paragneiss sample, fall in the range exhibited by granitoid plutons derived from mixed supracrustal-mantle sources (i.e., 

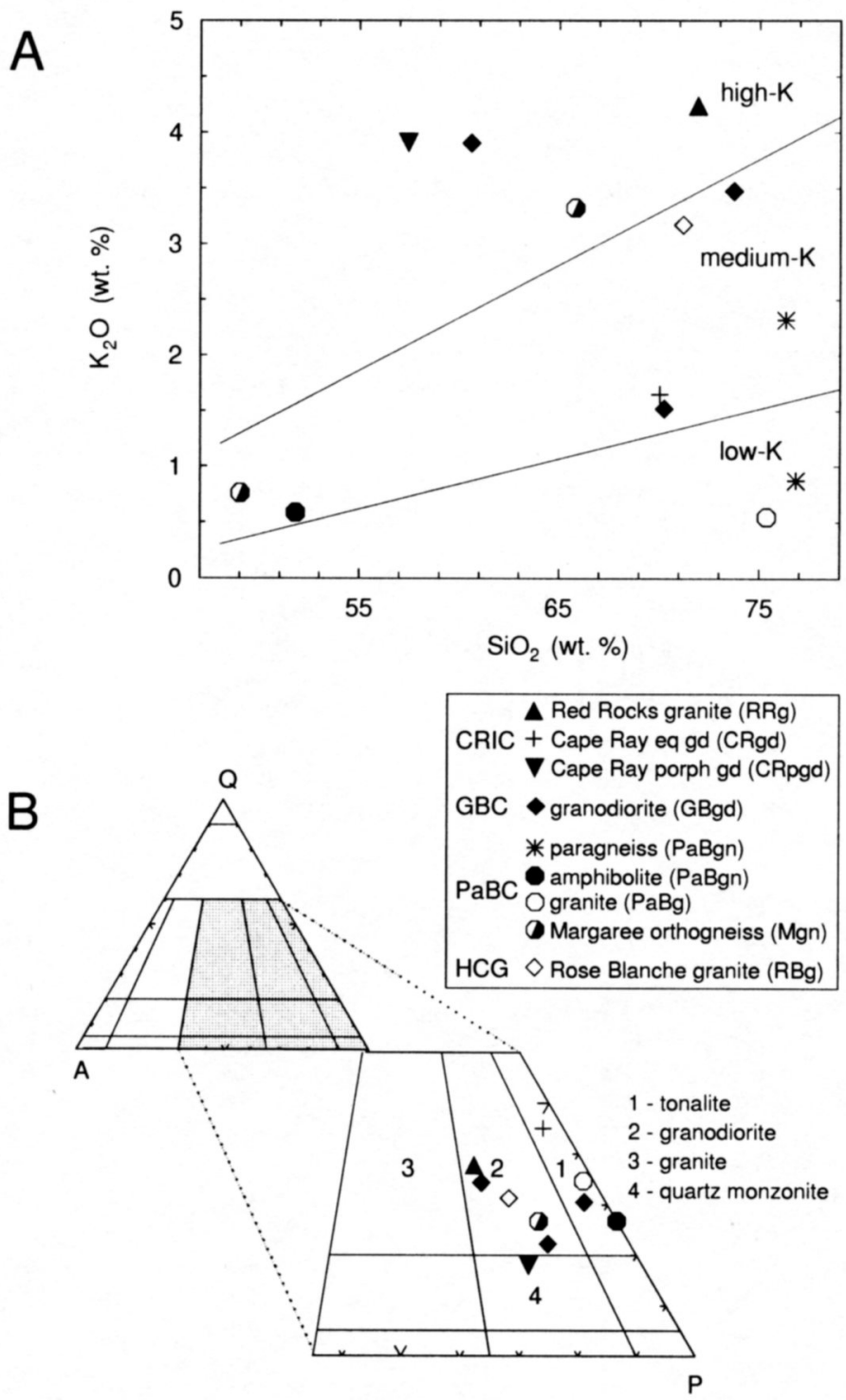

Fig. 3. (A) Silica versus potassium plot for units in southwestern Newfoundland (after Middlemost, 1985); (B) Mesonormative quartz-plagioclase-K-feldspar granite classification diagram; diagrams modified after Le Maitre (1989). Key to symbols given beside diagrams.

+8 to $+10 \%$ ) (Taylor, 1978,1988 ). The elevated $\delta^{18} \mathrm{O}$ value $(+12.7 \%)$ of Grand Bay granodiorite sample 168 is attributed to intense deformation accompanied by extensive lowtemperature sericite and carbonate alteration (see loss on ignition (LOI) values in Table 3).

Feldspar $\mathrm{Pb}$ isotopic data, which are available for only four granitoid samples, are shown in Figure 6 on conventional $\mathrm{Pb}-\mathrm{Pb}$ plots. K-feldspars from the Cape Ray Igneous Complex and the Rose Blanche granite exhibit similar, somewhat radiogenic compositions. In contrast, albite from the Port aux Basques granite is remarkably radiogenic, indicating input from old crustal material. Duplicate residue and leachate analyses from this sample yielded similar radiogenic results. No obvious correlations exist between $\delta^{18} \mathrm{O}, \varepsilon_{\mathrm{Nd}}$ or $\mathrm{Pb}$ isotopic values and whole rock chemistry.

\section{TECTONOSTRATIGRAPHIC ZONE IDENTIFICATION AND ITS IMPLICATIONS}

Isotopic and geochemical comparisons between tectonic divisions in southwest Newfoundland and various Appalachian tectonostratigraphic zones and subzones are discussed below, starting from the northwest:

\section{Cape Ray Igneous Complex}

The Cape Ray Igneous Complex forms part of the Dashwoods subzone (Fig. 2) and contains remnants of the Cambro-Ordovician Notre Dame arc. Support for this interpretation is given by the fact that its Ordovician plutons are low-K (Fig. 3A), metaluminous (Table 3 ), and have $\varepsilon_{\mathrm{Nd}}$, $\delta^{18} \mathrm{O}$ and $\mathrm{K}$-feldspar $\mathrm{Pb}$ isotopic signatures within the ranges exhibited by similar age plutons in the northern Dashwoods and Notre Dame subzones (Figs. 5, 6). Like almost all other Notre Dame arc plutons, the strongly negative $\varepsilon_{\mathrm{Nd}}(0.43 \mathrm{Ga})$, mainly juvenile or mantle-like $\delta^{18} \mathrm{O}$, and metaluminous characteristics of the Cape Ray granitoids indicate major contributions from old (>1.2 Ga; based on $\mathrm{T}_{\mathrm{DM}}$ ages in Table 4) infracrustal sources.

\section{Grand Bay complex}

Based mainly on metasedimentary rock characteristics, the Ordovician Grand Bay complex has been equated with rocks of the western Exploits subzone (van Staal et al., 1992). The positive $\varepsilon_{\mathrm{Nd}}$ values of the Grand Bay granodiorite samples are distinct from the negative values characteristic of contemporaneous Gander Zone plutons in Newfoundland and New Brunswick (Table 2; Fig. 5). Although they overlap the upper range of Ordovician Notre Dame arc plutons, $\varepsilon_{\mathrm{Nd}}$ values of those plutons are almost all strongly negative (mean $\left.\varepsilon_{\mathrm{Nd}}(0.43 \mathrm{Ga})=-7 \pm 3\right)$ (Whalen et al., 1997). The positive $\varepsilon_{\mathrm{Nd}}$ values of the Grand Bay granodiorite are what would be expected of plutons emplaced within a relatively juvenile arc setting. Except for petrographically strongly altered sample $168, \delta^{18} \mathrm{O}$ values $(+6.3$ to $+6.5 \%)$ lie in the range of granites derived from juvenile or mantle-like sources, but are somewhat lower than other Exploits subzone plutons (Table 2). Overall, these results are compatible with the Grand Bay complex representing a sliver of the Exploits subzone.

\section{Port aux Basques Complex}

The Port aux Basques Complex, from which we have analyzed a variety of units, has been equated to the Gander Zone. The $\varepsilon_{\mathrm{Nd}}(0.43 \mathrm{Ga})$ signatures of Gander margin sediments $(-8$ to -7$)$ are distinct from the more negative values (i.e., $\sim-11$; Table 2) obtained for sediments of equivalent age deposited on the Laurentian margin (Fryer et al., 1992) or in the Notre Dame subzone (Whalen et al., 1997). Thus, the $\varepsilon_{\mathrm{Nd}}(0.43$ $\mathrm{Ga}$ ) values (-8.5) obtained from Port aux Basques paragneiss are in keeping with its interpretation as part of the Gander 


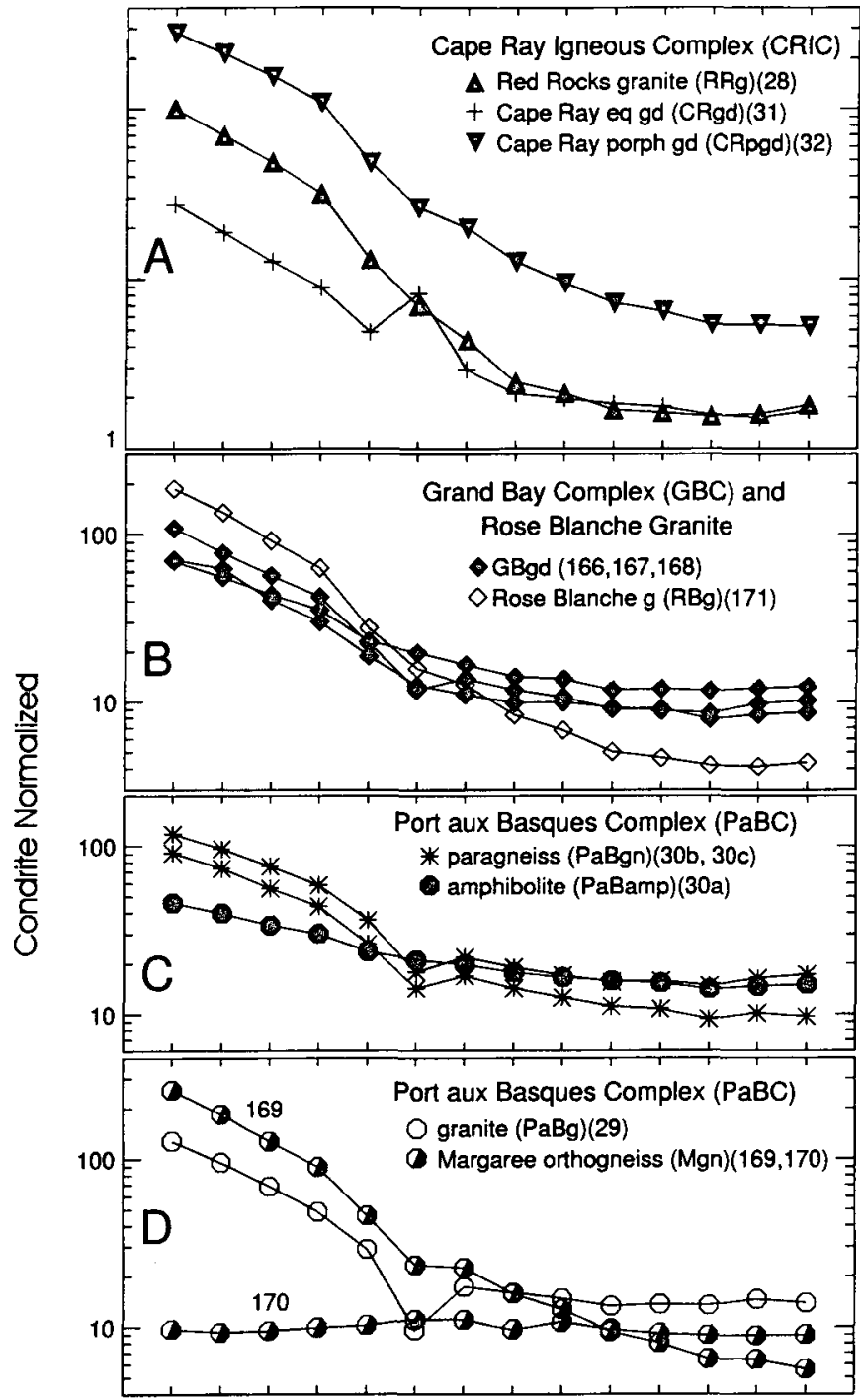

La Ce Pr Nd Sm Eu Gd Tb Dy Ho Er Tm Yb Lu

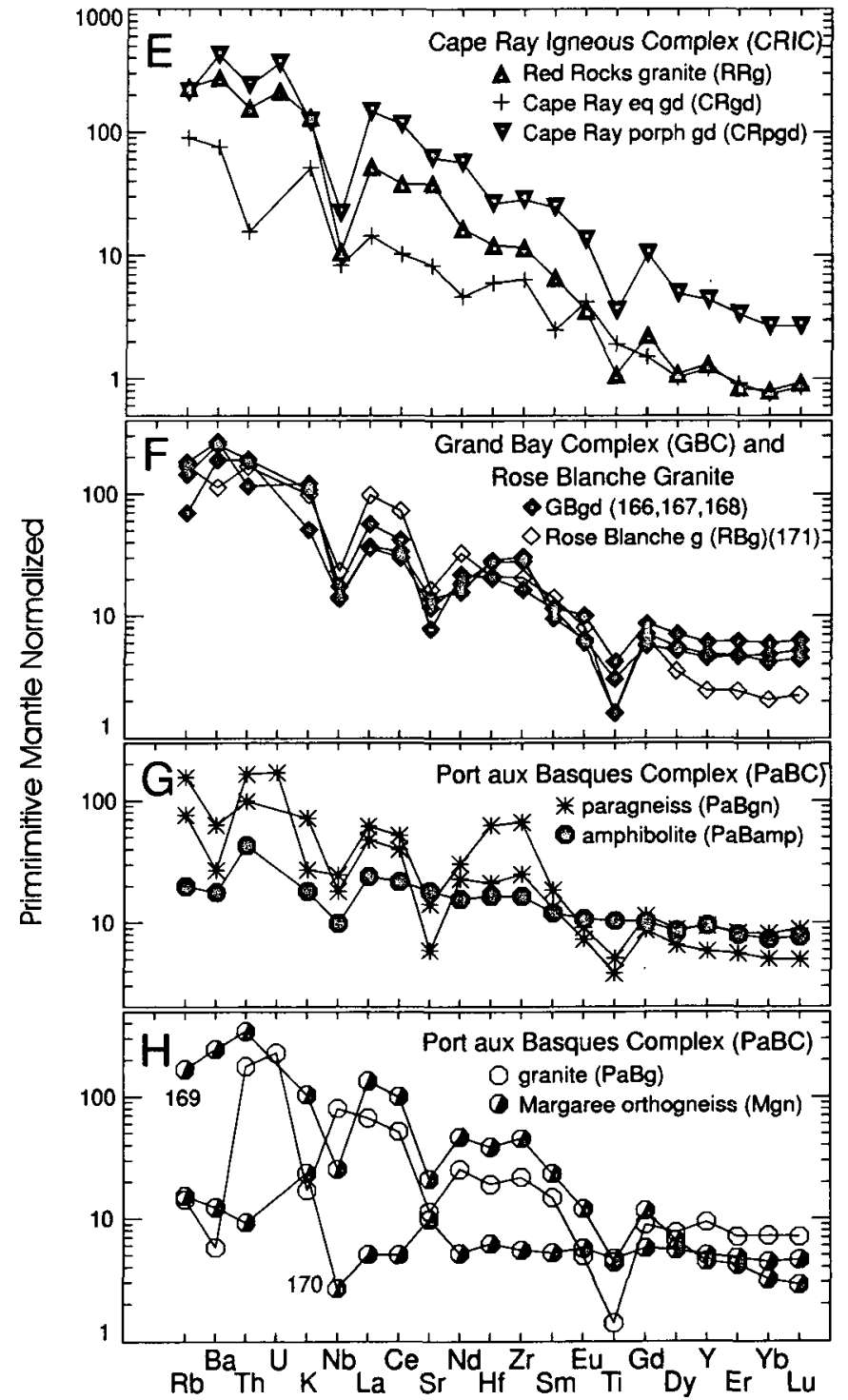

Fig. 4. Chondrite-normalized rare earth (A to D) and primitive mantle normalized extended element (E to $H$ ) plots for units in southwestern Newfoundland. Normalizing values for chondrite and primordial mantle from Sun (1982) and Taylor and McLennan (1985). Units are subdivided by the tectonic division within which they occur (for division locations, see Figure 1).

Zone. Its somewhat low $\delta^{18} \mathrm{O}$ values $(+9.8$ to $+10.1 \%$ ) may reflect Port aux Basques Complex sediments being more immature or less pelitic (Fig. 5) (cf. Longstaffe and Schwarcz, 1977). The pre-Neoproterozoic basement source sampled by Gander Zone trailing margin-type sandstones, such as the Port aux Basques paragneiss, was probably the composite Archean to Mesoproterozoic Amazonian craton (van Staal et al., 1996b), which consists of older crust that is exposed in the Avalon Zone (see Avalon Zone $\varepsilon_{\mathrm{Nd}}(0.43 \mathrm{Ga}$ ) values in Table 2) (Whalen et al., 1996b).

The $\varepsilon_{\mathrm{Nd}}$ and $\delta^{18} \mathrm{O}$ values of an amphibolite sheet $(+2.4$ and $+8.8 \%$ ) and a Margaree orthogneiss granodiorite $(+1.1$ and +9.51 ), interpreted by Schofield et al. (1993) to be consanguineous at $470 \mathrm{Ma}$, may reflect mixing between a depleted mantle-derived magma $\left(\varepsilon_{\mathrm{Nd}^{\sim}}+8 ; \delta^{18} \mathrm{O} \sim+6-8 \%\right)$ and melts derived from Port aux Basques paragneiss $\left(\varepsilon_{\mathrm{Nd}} \sim-8\right.$; $\delta^{18} \mathrm{O} \sim+10 \%$ ), which both intrude. If so, the negative $\mathrm{Nb}$ anomalies exhibited by these units (Fig. 4G,H) reflect crustal contamination rather than volcanic-arc affinity. The positive $\varepsilon_{\mathrm{Nd}}$ signature and dioritic to granodioritic composition of the Margaree orthogneiss is distinct from Ordovician Gander Zone plutons in Newfoundland (Kerr et al., 1995) and New Brunswick (Whalen, 1993; Whalen et al., 1996b) (Table 2). Compositionally, the Margaree orthogneiss resembles similar age Notre Dame arc plutons, but almost all these plutons have negative $\varepsilon_{\mathrm{Nd}}(0.43 \mathrm{Ga})$ signatures. It does, however, resemble plutons of this age within the Exploits subzone (Table 2). This is compatible with the Margaree orthogneiss plus the Port aux Basques amphibolite dykes being interpreted as related to the opening of the Tetagouche-Exploits backarc basin during the late Arenig to Llanvirn (Scholfield $e t$ al., 1993; van Staal, 1994; van Staal et al., 1994). Granodiorites within the Grand Bay complex were emplaced at the same time as these units.

The Late Ordovician, early-syntectonic Port aux Basques granite (actually of low-K tonalitic composition; see Fig. 
Table 4. Isotopic analyses and sample locations for units in southwestern Newfoundland.

\begin{tabular}{|c|c|c|c|c|c|c|c|c|c|c|c|c|c|}
\hline Division & CRIC & CRIC & CRIC & GBC & GBC & GBC & $\mathrm{PaBC}$ & $\mathrm{PaBC}$ & $\mathrm{PaBC}$ & $\mathrm{PaBC}$ & $\mathrm{PaBC}$ & $\mathrm{PaBC}$ & HCG \\
\hline Unit & CRgd & CRpgd & $\mathrm{RRg}$ & GBgd & GBgd & GBgd & PaBamp & PaBgn & PaBgn & $\mathrm{PaBg}$ & Mgn & Mgn & $\mathrm{RBg}$ \\
\hline WXNF\# & 31 & 32 & 28 & 166 & 167 & 168 & $30 \mathrm{a}$ & $30 c$ & $30 \mathrm{~b}$ & 29 & 170 & 169 & 171 \\
\hline$\delta^{18} \mathrm{O}(\%)$ & +6.8 & +8.7 & +8.7 & +6.3 & +6.5 & +12.7 & +8.8 & +10.1 & +9.8 & +7.5 & - & +9.5 & +9.5 \\
\hline${ }^{206} \mathrm{~Pb} /{ }^{204} \mathrm{~Pb}$ & - & 18.652 & 18.410 & - & - & - & - & - & - & 20.044 & - & - & 18.244 \\
\hline${ }^{207} \mathrm{~Pb} /{ }^{204} \mathrm{~Pb}$ & - & 15.596 & 15.692 & - & - & - & - & - & - & 15.818 & - & - & 15.609 \\
\hline${ }^{208} \mathrm{~Pb} /{ }^{204} \mathrm{~Pb}$ & - & 38.098 & 38.072 & - & - & - & - & - & $\cdot$ & 39.986 & - & - & 38.067 \\
\hline${ }^{143} \mathrm{Nd} d^{144} \mathrm{Nd}_{\mathrm{m}}$ & 0.511864 & 0.512056 & 0.511999 & 0.512441 & 0.512484 & 0.512485 & 0.512638 & 0.511979 & 0.511984 & 0.512809 & - & 0.512388 & 0.512388 \\
\hline${ }^{147} \mathrm{Sm} /{ }^{144} \mathrm{Nd}_{\mathrm{m}}$ & 0.0984 & .0867 & 0.0803 & 0.1158 & 0.1037 & 0.1281 & 0.1568 & 0.1167 & 0.1168 & 0.1144 & - & 0.0971 & 0.0843 \\
\hline${ }^{143} \mathrm{Nd} /{ }^{144} \mathrm{Nd}_{\mathrm{i}}$ & 0.511549 & 0.511779 & 0.511778 & 0.512084 & 0.512165 & 0.512091 & 0.512155 & 0.511620 & 0.511624 & 0.512470 & - & 0.512089 & 0.512157 \\
\hline Age (Ma) & 469 & 488 & 420 & 470 & 470 & 470 & 470 & $>500$ & $>500$ & 453 & 470 & 470 & 418 \\
\hline$\varepsilon_{N d}(T)$ & -9.2 & -4.5 & -6.2 & +1.0 & +2.6 & +1.1 & +2.4 & - & - & +8.1 & - & +1.1 & +1.1 \\
\hline$\varepsilon_{\mathrm{Nd}}(0.43 \mathrm{Ga})$ & -9.7 & -5.3 & -6.1 & +0.6 & +2.1 & +0.8 & +2.2 & -8.5 & -8.4 & +7.9 & - & 0.0 & +1.3 \\
\hline $\mathrm{T}_{\mathrm{DM}}(\mathrm{Ga})$ & 1.7 & 1.3 & 1.3 & 1.1 & 0.9 & 1.2 & 1.4 & 1.8 & 1.8 & 0.5 & - & 1.0 & 0.9 \\
\hline $\begin{array}{l}\text { Locations } \\
\text { NTS Sheet }\end{array}$ & $110 / 11$ & $110 / 11$ & $110 / 11$ & $110 / 11$ & $110 / 11$ & $110 / 11$ & $110 / 11$ & $110 / 11$ & $110 / 11$ & $110 / 11$ & $110 / 11$ & $110 / 11$ & $110 / 10$ \\
\hline UTM Zone & 21 & 21 & 21 & 21 & 21 & 21 & 21 & 21 & 21 & 21 & 21 & 21 & 21 \\
\hline Northing & 52791 & 52766 & 52826 & 52729 & 52744 & 52764 & 52722 & 52722 & 52722 & 52728 & 52702 & 52702 & 52739 \\
\hline Easting & 3323 & 3268 & 3271 & 3338 & 3366 & 3327 & 3389 & 3389 & 3389 & 3413 & 3464 & 3464 & 3713 \\
\hline
\end{tabular}

Notes: Pluton names correspond to pluton abbreviations in Table 1; locations of divisions given in Figure 2. Subscripts $i$ and $m$ denote initial and measured, respectively.

3 ), which was probably generated during the early stages of closure of the Tetagouche-Exploits back-arc basin (van Staal, 1994; van Staal et al., 1994), was previously interpreted as representing partial melts of its host paragneiss (Chorlton and Knight, 1983). Its depleted-mantle-like $\varepsilon_{\mathrm{Nd}}$ plus mantle-like $\delta^{18} \mathrm{O}(+7.5 \%)$ isotopic signatures make the Port aux Basques granite distinct from other granites emplaced into the Gander margin in Newfoundland (Kerr et al., 1995) and New Brunswick (Whalen, 1993; Whalen et al., 1996b) (Table 2), and dictate derivation from a juvenile depleted-mantle-like source. However, with respect to $\mathrm{Pb}$, this granite is more radiogenic than either Paleozoic Gander Zone plutons (Whalen et al., 1996b) or Precambrian Avalonian basement in New Brunswick (Fig. 6). Our Nd isotopic results (Fig. 5) suggest very little input to this granite from its paragneissic wall-rocks. However, a less positive $\varepsilon_{\mathrm{Nd}}(0.47 \mathrm{Ga})$ value of +2 reported from this granite by Fryer $e$ t al. (1992), its radiogenic or 'old crustal' $\mathrm{Pb}$ signature (Fig. 6), and the relatively low $\delta^{18} \mathrm{O}$ value (+9.8\%) obtained from a Port aux Basques paragneiss are compatible with variable input from paragneiss to the granite sheets. If so, zoning in $\varepsilon_{\mathrm{Nd}}$ may be present within individual granite sheets, i.e., most positive in the centre of a sheet, the location from which our sample was collected.

\section{Rose Blanche granite}

The Silurian Rose Blanche granite has been interpreted as a syn-collisional, syn-peak-temperature metamorphism pluton which formed as a result of westward-directed subduction and underthrusting by the Gander margin (Dunning et al., 1991; Burgess et al., 1995; van Staal et al., 1994). This peraluminous granite petrographically resembles some Gander Zone granites, but its normalized geochemical pattern is not similar to those of Gander plutons (see Whalen et al., 1996b), more closely resembling the Silurian Red Rock pluton of the Cape Ray Igneous Complex (Fig. 4). More significantly, its positive $\varepsilon_{\mathrm{Nd}}(0.43 \mathrm{Ga})$ signature is distinct from Gander Zone plutons (Table 1). These characteristics resemble most plutons in the Exploits subzone (Table 2) (Fryer et al., 1992; Whalen et al., 1994b). Also, its $\mathrm{Pb}$ isotopic signature, which is less-radiogenic than Gander Zone plutons in New Brunswick (Whalen et al., 1994a,b), overlaps $\mathrm{Pb}$ isotopic compositions displayed by the 'Central Group' of Ayuso and Bevier (1991) (Fig. 6), plutons emplaced into the Dunnage Zone of New Brunswick and Maine. The peraluninous petrographic characteristics, positive $\varepsilon_{\mathrm{Nd}}$ and somewhat elevated $\delta^{18} \mathrm{O}$ $(+9.5 \%)$ of the Rose Blanche granite could be attributed to derivation from immature arc-type volcaniclastic sediments (cf., Longstaffe and Schwarcz, 1977). A gradual increase in the volume of metatexite and stromatic in situ leucosome in the Harbour Le Cou Group migmatites toward their contact with this pluton suggests a significant input by partial melting of the Harbour Le Cou Group and supports this petrogenetic model. Also, this model may explain why this syn-collisional pluton has geochemical and isotopic characteristics similar to pre-collisional Exploits subzone plutons. 


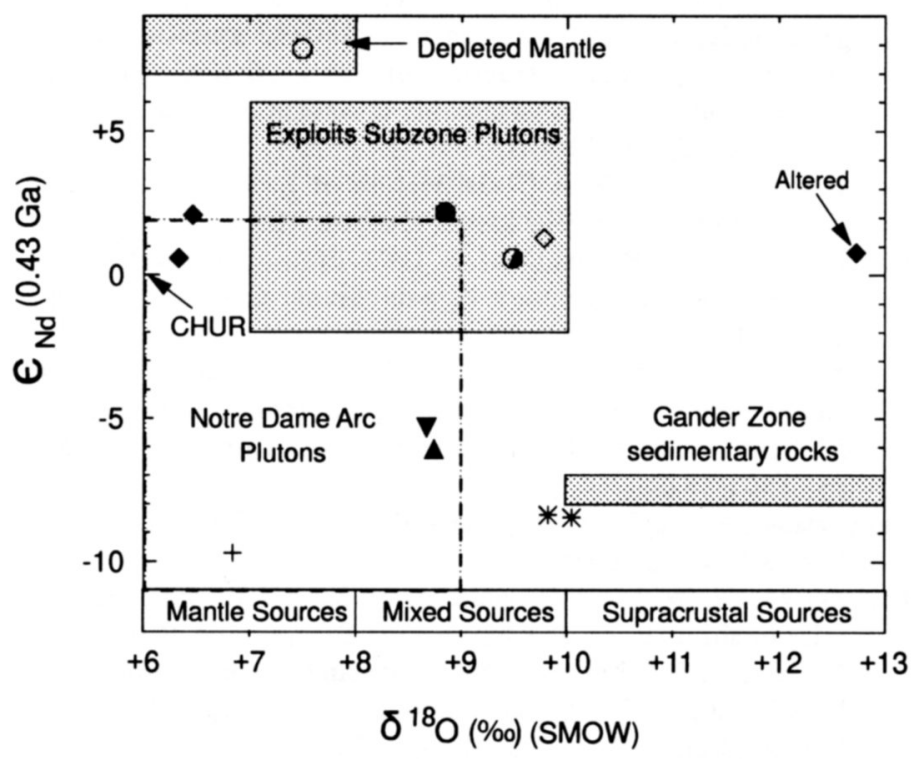

Fig. 5. $\varepsilon_{\mathrm{Nd}}(0.43 \mathrm{Ga})$ vs. $\delta^{18} \mathrm{O}$ (SMOW) for units in southwestern Newfoundland; symbols as in Figures 2 and 3. Also shown are the fields of Ordovician Notre Dame arc and Exploits Paleozoic plutons from Table 2 and the ranges in $\delta^{18} \mathrm{O}$ (SMOW) exhibited by various sources (bottom of diagram) from Taylor $(1978,1988)$.

\section{Discussion}

This reconnaissance study suggests that isotopic plus geochemical analyses can be a useful aid in terrane identification in highly deformed portions of orogenic belts. In general, results obtained in this study are compatible with or support previous correlations which were arrived at following careful stratigraphic, structural, metamorphic and geochronological studies. In addition, this study has provided some new insights about the evolution of this area.

(1) Based on its unexpected isotopic characteristics, the Late Ordovician Port aux Basques granite (tonalite) formed either via fractionation from a MORB-like magma or by partial melting of recently formed (i.e., juvenile), depletedmantle-derived, hydrous crust. In the second preferred option, a depleted mantle-derived underplate or intraplate may have formed at the time (ca. $470 \mathrm{Ma}$ ) of the opening of the TetagoucheExploits back-arc basin, at which time the Port aux Basques amphibolite dykes and Margaree orthogneiss were emplaced. The thermal conditions necessary to generate the Port aux Basques granite at $453 \mathrm{Ma}$ by partial melting of such a juvenile underplate may have been generated during subduction of a spreading ridge (van Staal et al., in review).

(2) The isotopic characteristics of Ordovician Notre Dame arc plutons suggest generation within an Andean-type continental arc which formed on the Laurentian margin; hence a subduction polarity reversal must have taken place after the Early Ordovician obduction of the suprasubduction zone oceanic tract (van Staal et al., in review).

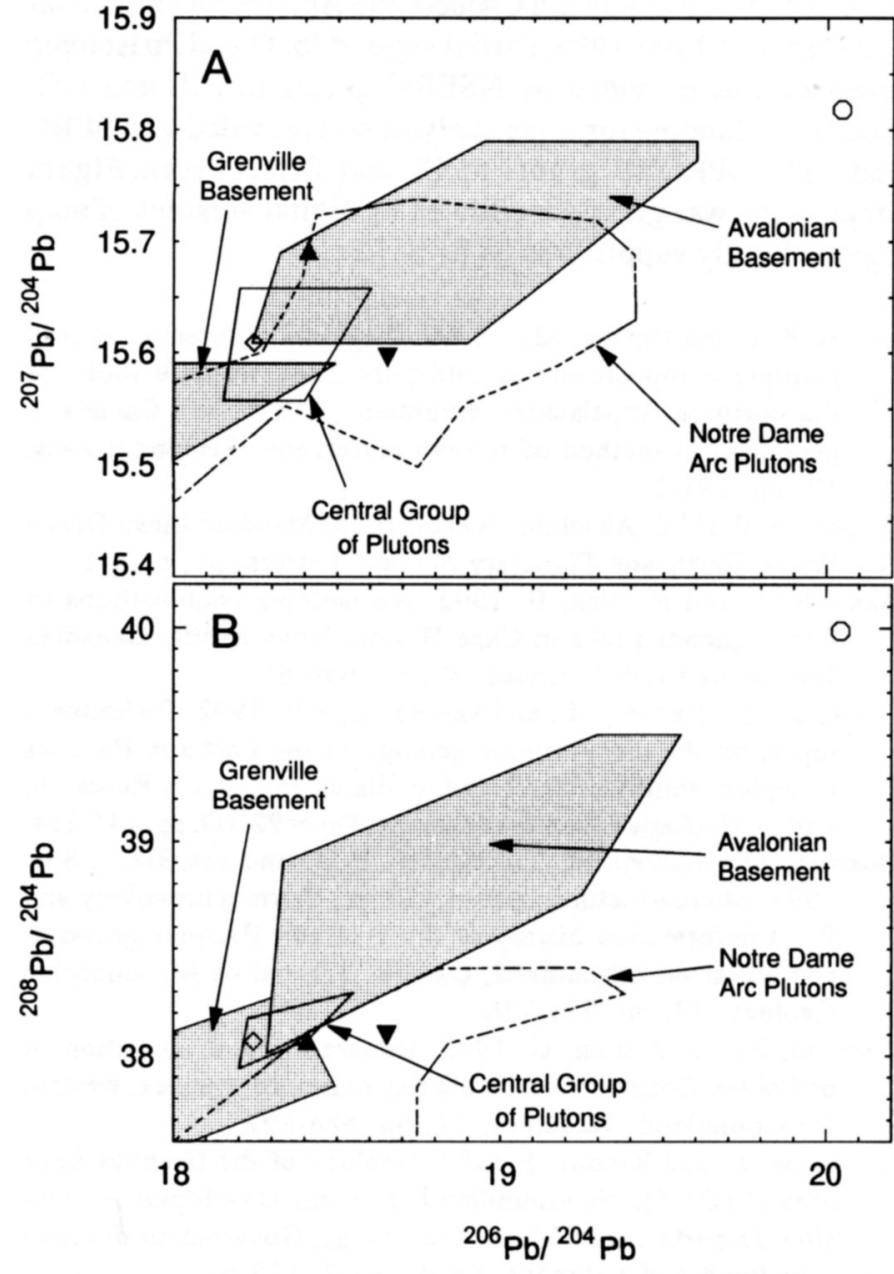

Fig. 6. Plot of ${ }^{206} \mathrm{~Pb} / 204 \mathrm{~Pb}$ versus (A) ${ }^{207} \mathrm{~Pb} / 204 \mathrm{~Pb}$, and (B) ${ }^{208} \mathrm{~Pb} /$ ${ }^{204} \mathrm{~Pb}$ for feldspars from southwestern Newfoundland granitoid samples; comparison fields for Grenville basement, Precambrian Avalon Zone granitoid rocks and the 'Central Group' of plutons (after Ayuso and Bevier, 1991) and Ordovician Notre Dame arc plutons (after Whalen et al., 1997) are also shown. Data of this study were recalculated to $400 \mathrm{Ma}$ using $\mu=10$ and $238 \mathrm{Th} / 238 \mathrm{U}$ $=3.5$, the values that Ayuso and Bevier (1991) use for their 'Central Group' of plutons.

\section{ACKnowledgements}

An earlier version of this manuscript benefited from critical reviews by S. Lin, K.L. Currie, R.A. Creaser and two anonymous reviewers. J. Whalen benefited from assistance in sample collection and discussions with K.L. Currie. C. van Staal gratefully acknowledges the important contributions made by J. Burgess, L. Hall, S. Lin, D. Schofield, and P. Valverde to the geological mapping of southwest Newfoundland. We thank P. Middlestead and D. Harper for assistance in the stable isotope laboratory, $\mathrm{F}$. Robert for help in the $\mathrm{Pb}$ measurements and C. Collins for help in the trace element and $\mathrm{Nd}$ isotopic analyses. This project was funded under 
the Canada-Newfoundland Cooperation Agreement on Mineral Development 1990-1995. Partial support for O and Pb isotopic analyses was provided by NSERC grants to FJL and CG. Additional funding for some analyses was provided by NSERC and LITHOPROBE grants to GJ and Brian Fryer. Figure preparation was greatly facilitated by digital versions of map figures kindly supplied to us by S. Lin.

Ayuso, R.A. and Bevier, M.L. 1991. Regional differences in lead isotopic compositions of feldspars from plutonic rocks of the northern Appalachian mountains, U.S.A. and Canada: a geochemical method of terrane correlation. Tectonophysics, 10, pp. 191-212.

BAERTSCHI, P. 1976. Absolute ${ }^{18} \mathrm{O}$ content of Standard Mean Ocean Water. Earth and Planetary Science Letters, 31, p. 341.

BARR, S.M. and Hegner, E. 1992. Nd isotopic compositions of felsic igneous rocks in Cape Breton, Nova Scotia. Canadian Journal of Earth Sciences, 29, pp. 650-657.

Burgess, J.L., Brown, M., and van StaAl, S.R. 1992. Preliminary report on the metamorphic geology of the Port aux Basques Complex, southwestern Newfoundland. In Current Research, Part D, Geological Survey of Canada, Paper 92-1D, pp. 145-154.

Burgess, J.L., Brown, M., Dallmeyer, R.D., and van Staal, S.R. 1995. Microstructure, metamorphism, thermochronology and P-T-t deformation history of the Port aux Basques gneisses, southwest Newfoundland, Canada. Journal of Metamorphic Geology, 13, pp. 751-776.

Cawood, P.A. and Suhr, G. 1992. Generation and obduction of ophiolites: Constraints from the Bay of Islands complex, western Newfoundland. Tectonics, 11, pp. 884-897.

Chortton, L. and Knight, I. 1983. Geology of the Grandys Lake area (110/15), Newfoundland. Mineral Development Division, Department of Mines and Energy, Government of Newfoundland and Labrador, Report 83-7, $125 \mathrm{p}$.

DePaolo, D.J. 1988. Neodymium Isotope Geochemistry: An Introduction. Springer-Verlag, New York, 187 p.

Dubé, B., Dunning, G.R., Lauziere, K., and Roddick, J.C. 1996. New insights into the Appalachian Orogen from geology and geochronology along the Cape Ray fault zone, southwest Newfoundland. Geological Society of America Bulletin, 108, pp. 101-116.

Dunning, G.R. and Chorlton, L.B. 1985. The Annieopsquotch ophiolite belt of southwest Newfoundland: Geology and tectonic significance. Geological Society of America Bulletin, 96, pp. 1466-1476.

Dunning, G.R., Swinden, H.S., Kean, B.F., Evans, D.T.W., and Jenner, G.A. 1991. A Cambrian island arc in Iapetus: geochronology and geochemistry of the Lake Ambrose volcanic belt, Newfoundland Appalachians. Geological Magazine, 128, pp. 1-17.

Fryer, B.J., Kerr, A., Jenner, G.A., and Longstaffe, F.J. 1992. Probing the crust with plutons: regional isotopic geochemistry of granitoid intrusions across insular Newfoundland. Newfoundland Geological Surveys Branch, Report 92-1, pp. 119-140.

Hall, L.A.F., van StaAl, C.R., and William, H. 1994. Ordovician structural evolution of SW Newfoundland. Geological Association of Canada/Mineralogical Association of Canada, Program with Abstracts, 19, p. A46.

Jenner, G.A. and Swinden, H.S. 1993. The Pipestone Pond Complex, central Newfoundland: complex magmatism in an eastern Dunnage Zone ophiolite. Canadian Journal of Earth Sciences, 30 , pp. 434-448.
Kerr, A., Jenner, G.A., and Fryer, B.J. 1995. Sm-Nd isotopic geochemistry of Precambrian to Paleozoic granitoid suites and the deep-crustal structure of the southeast margin of the Newfoundland Appalachians. Canadian Journal of Earth Sciences, 32, pp. 224-245.

Le Maitre, R.W. 1989. A Classification of Igneous Rocks and Glossary of Terms. Blackwell, Oxford, $193 \mathrm{p}$.

Lin, S., van StaAl, C.R., and Dubé, B. 1994. Promontory-promontory collision in the Canadian Appalachians. Geology, 22, pp. 897-900.

Longstaffe, F.J. and Schwarcz, H.P. 1977. ${ }^{18} \mathrm{O} /{ }^{16} \mathrm{O}$ of Archean clastic metasedimentary rocks: a petrogenetic indicator for Archean gneisses. Geochemica et Cosmochimica Acta, 41, pp. 1303-1312.

MidDlemost, E.A.K. 1985. Magmas and Magmatic Rocks. Longman Group Limited, Essex.

Piasecki, M.A.J., Williams, H., and Colman-Sadd, S.P. 1990. Tectonic relationships along the Meelpaeg, Burgeo and Burlington LITHOPROBE transects in Newfoundland. In Current Research, Newfoundland Department of Mines and Energy, Geological Survey Branch, Report 90-1, pp. 327-339.

Quinlan, G.M., Hall, J., Williams, H., Wright, J.A., Coleman-Sadd, S.P., O'Brien, S.J., Stockmal, G.S., and Marillier, F. 1992. Lithoprobe onshore seismic reflection transects across the Newfoundland Appalachians. Canadian Journal of Earth Sciences, 29, pp. 1865-1877.

Schofield, D.I., Winchester, J.A., and van StaAl, S.R. 1993. The Isle aux Morts metabasalt, southwest Newfoundland. In Current Research, Part D, Geological Survey of Canada, Paper 93-1D, pp. 39-46.

Schofield, D.I., van StaAl, C.R., and Winchester, J.A. In press. Tectonic setting and regional significance of the "Port aux Basquess gneiss", SW Newfoundland. Journal of the Geological Society.

Swinden, H.S., Jenner, G.A., Fryer, B.J., Hertogen, J., and Roddick, J.C. 1990. Petrogenesis and paleotectonic history of the Wild Bight Group, an Ordovician rifted island arc in Central Newfoundland. Contributions to Mineralogy and Petrology, 105, pp. 219-241.

Sun, S.S. 1982. Chemical composition and origin of the Earth's primitive mantle. Geochimica et Cosmochimica Acta, 46, pp. 179-192.

TAYLOR, H.P., JR. 1978. Oxygen- and hydrogen-isotope studies of plutonic rocks. Earth and Planetary Science Letters, 38, pp. 177-210.

....- 1988. Oxygen, hydrogen and strontium isotope constraints on the origin of granites. Transactions of the Royal Society of Edinburgh. Earth Sciences, 79, pp. 317-338.

Taylor, S.R. and McLennan, S.M. 1985. The Continental Crust: Its Composition and Evolution. Blackwell, Oxford, 312 p.

van StaAl, C.R. 1994. Brunswick subduction complex in the Canadian Appalachians: Record of the Late Ordovician to Late Silurian collision between Laurentia and the Gander margin of Avalon. Tectonics, 13, pp. 946-962.

van StaAl, C.R., Winchester, J.A., Brown, M., and Burgess, J.L. 1991. A reconnaissance geotraverse through southwestern Newfoundland. In Current Research, Part D, Geological Survey of Canada, Paper 92-1D, pp. 133-143.

van Staal, C.R., Burgess, J.L., Hall, L., Lee, C., Lin, S., and Schofield, D.I. 1992. Geology of the Port aux Basques-Rose Blanche area (NTS 11-0/10 \& 11-O/11). In Report of Activities 1992, Newfoundland Department of Mines and Energy, Geological Survey Branch, pp. 41-43. 
van Staal, C.R., Dunning, G., Valverde, P., Burgess, J., and Brown, M. 1994. Arenig and younger evolution of the Gander margin: a comparison of the New Brunswick and Newfoundland segments. Atlantic Geology, 30, pp. 178-179.

van Staal, C.R., Hall, L., Schofield, D.I., and Valverde, P. 1996a. Geology Port aux Basques, Newfoundland, scale 1:25 000 (part of NTS 11-O/11). Geological Survey of Canada, Open File 3165.

van Staal, C.R., Sullivan, R.W., and Whalen, J.B. 1996b. Provenance and tectonic history of the Gander Margin in the Caledonian/ Appalachian orogen: implications for the origin and assembly of Avalonia. In Avalonian and Related Terranes of the Circum-North Atlantic. Edited by R.D. Nance and M.D. Thompson. Geological Society of America, Special Paper 304, pp. 347-367.

van Staal, C., Dewey, J.F., Mac Niocalll, C., and McKerrow, W.S. In review. The Cambrian-Silurian tectonic evolution of the northern Appalachians and British Caledonides: history of a complex, southwest Pacific-type segment of Iapetus. Geological Society, London, Special Publication.

Whalen, J.B. 1993. Geology, petrography and geochemistry of Appalachian granites in New Brunswick and Gaspésie, Quebec. Geological Survey of Canada, Bulletin 436, 124 p.

Whalen, J.B, Hegner, E., and Jenner, G.A. 1989. Nature of Canadian Appalachian basement terranes as inferred from a Nd isotopic transect. Geological Society of America, Abstracts with Program, 21, p. A201.

Whalen, J.B., Jenner, G.A., Currie, K.L., Barr, S.M., Longstaffe, F.J., and Hegner, E. 1994a. Geochemical and isotopic characteristics of granitoids of the Avalon Zone, southern New Brunswick: Possible evidence for repeated delamination events. Journal of Geology, 102, pp. 269-282.

Whalen, J.B., Jenner, G.A., Hegner, E., Gariépy, C., and Longstaffe, F.J. 1994b. Geochemical and isotopic $(\mathrm{Nd}, \mathrm{O}$, and $\mathrm{Pb})$ constraints on granite sources in the Humber and Dunnage zones, Gaspésie, Quebec, and New Brunswick: implications for tectonics and crustal structure. Canadian Journal of Earth Sciences, 31, pp. 323-340.
Whalen, J.B., Fyffe, L.R., Longstaffe, F.J., and Jenner, G.A. 1996a. The position and nature of the Gander-Avalon boundary, southern New Brunswick, based on geochemical and isotopic data from granitoid rocks. Canadian Journal of Earth Sciences, 33, pp. 129-139.

Whalen, J.B., Jenner, G.A., and Longstaffe, F.J. 1996b. Nature and evolution of the eastern margin of Iapetus: geochemical and isotopic constraints from Siluro-Devonian granitoid plutons in the New Brunswick Appalachians. Canadian Journal of Earth Sciences, 33, pp. 140-155.

Whalen, J.B., Jenner, G.A., Longstaffe, F.J., Gariépy, C., and ROBERT, F. 1996c. Geochemical and isotopic $(\mathrm{Nd}, \mathrm{O}, \mathrm{Pb}$ and Sr) constraints on A-type granite petrogenesis based on the Topsails igneous suite, Newfoundland Appalachians. Journal of Petrology, 37, pp. 1463-1489.

Whalen, J.B., Jenner, G.A., Longstaffe, F.J., Gariépy, C., and FRYER, B.J. 1997. Implications of granitoid geochemical and isotopic $(\mathrm{Nd}, \mathrm{O}, \mathrm{Pb}$ ) data from the Cambro-Ordovician Notre Dame arc for the evolution of the Central Mobile Belt, Newfoundland Appalachians. In The Nature of Magmatism in the Appalachian Orogen: Boulder, Colorado. Edited by K.A. Sinha, J.B. Whalen, and J. Hogan. Geological Society of America, Memoir 191, pp. 367-395.

Williams, H. 1979. Appalachian Orogen in Canada. Canadian Journal of Earth Sciences, 14, pp. 792-807.

Williams, H., Colman-SAdd, S.P, and Swinden, H.S. 1988. Tectonic-stratigraphic subdivision of central Newfoundland. Geological Survey of Canada, Paper 88-1B, pp. 91-98

Winchester, J. and van StAAL, C.R. 1995. Volcanic and sedimentary terrane correlation between the Dunnage and Gander zones of the Canadian Appalachians and the British Caledonides reviewed. In New Perspectives in the Appalachian-Caledonian Orogen. Edited by J.P. Hibbard, C.R. van Staal, and P.A. Cawood. Geological Association of Canada, Special Paper 41, pp. 95-114. 